\title{
'n Hermeneutiek vir Teologiese interpretasie van die Bybel: Metodologiese besinning
}

\begin{tabular}{|c|c|}
\hline $\begin{array}{l}\text { Author: } \\
\text { Anneke Viljoe }\end{array}$ & \\
\hline $\begin{array}{l}\text { Affiliation: } \\
\text { 'Department } \\
\text { Testament Stu } \\
\text { Theology, Uni } \\
\text { Pretoria, Sout }\end{array}$ & $\begin{array}{l}\text { f Old } \\
\text { dies, Faculty of } \\
\text { Jersity of } \\
\text { Africa }\end{array}$ \\
\hline $\begin{array}{l}\text { Research Proj } \\
\text { Registration: } \\
\text { Project Leade } \\
\text { Fouché @ } \\
\text { Project Numb }\end{array}$ & $\begin{array}{l}\text { ect } \\
\text { r: A.B. Geyser- } \\
\text { er: } 1258230\end{array}$ \\
\hline $\begin{array}{l}\text { Description: } \\
\text { Dr Anneke Vilj } \\
\text { participating i } \\
\text { project, 'Seco } \\
\text { Literature and } \\
\text { directed by Dr } \\
\text { Geyser-Fouch } \\
\text { of Old Testam } \\
\text { Faculty of The } \\
\text { University of }\end{array}$ & $\begin{array}{l}\text { oen is } \\
\text { the research } \\
\text { id Temple } \\
\text { Qumran', } \\
\text { Ananda } \\
\text { É, Department } \\
\text { ent Studies, } \\
\text { ology, } \\
\text { 'retoria. }\end{array}$ \\
\hline $\begin{array}{l}\text { Correspondin } \\
\text { Anneke Viljoe } \\
\text { anchri@mwe }\end{array}$ & $\begin{array}{l}\text { g author: } \\
\text { h, } \\
\text {.co.za }\end{array}$ \\
\hline $\begin{array}{l}\text { Dates: } \\
\text { Received: } 20 \\
\text { Accepted: } 17 \\
\text { Published: } 19\end{array}$ & $\begin{array}{l}\text { ec. } 2016 \\
\text { Mar. } 2017 \\
\text { June } 2017\end{array}$ \\
\hline $\begin{array}{l}\text { How to cite th } \\
\text { Viljoen, A., } 20 \\
\text { Hermeneutiel } \\
\text { interpretasie } \\
\text { Metodologies } \\
\text { HTS Teologies } \\
\text { Theological St } \\
\text { a4497. https:/ } \\
\text { 10.4102/hts.v }\end{array}$ & $\begin{array}{l}\text { is article: } \\
17, \text { "n } \\
\text { vir Teologiese } \\
\text { an die Bybel: } \\
\text { besinning', } \\
\text { Studies/ } \\
\text { udies 73(1), } \\
\text { doi.org/ } \\
\text { 73i1.4497 }\end{array}$ \\
\hline $\begin{array}{l}\text { Copyright: } \\
\text { (C) 2017. The } \\
\text { Licensee: AOS } \\
\text { is licensed un } \\
\text { Creative Comr } \\
\text { Attribution Lic }\end{array}$ & $\begin{array}{l}\text { uthors. } \\
\text { S. This work } \\
\text { ler the } \\
\text { nons } \\
\text { ense. }\end{array}$ \\
\hline Read online: & \\
\hline 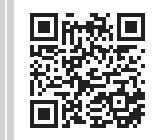 & $\begin{array}{l}\text { Scan this QR } \\
\text { code with your } \\
\text { smart phone or } \\
\text { mobile device } \\
\text { to read online. }\end{array}$ \\
\hline
\end{tabular}

The publication of several series of theological commentaries since the year 2000 marked the entrance of the discipline Theological interpretation of the Bible on the hermeneutical front. A lack of well-developed methodological considerations, underlying the practice of Theological interpretation of the Bible has, however, handicapped the theological interpretation of Bible texts. It is the aim of this article to contribute to the development thereof. Three metahermeneutical aspects that make up the broad methodological foundation of Theological interpretation of the Bible, namely metaphysics, epistemology and ethics are explored.

\section{Inleiding}

Die hernude belangstelling in en die gepaardgaande opkoms van Teologiese interpretasie van die Bybel sedert die begin van die huidige eeu bied 'n vrugbare werkgebied waarbinne OuTestamentiese wetenskap die ontwikkeling van alternatiewe hermeneutiese benaderings tot die teks van die Bybel kan ondersoek. Die publikasie van verskeie reekse teologiese kommentare sedert die jaar 2000 merk die toetrede van hierdie alternatiewe interpretasiebenadering tot die Bybelteks binne die hermeneutiese kader $^{1}$ (kyk ook Adam et al. 2006:8; Goldingay 2012:663; Meadowcroft 2013:1; Vanhoozer 2008a:15). Teologiese interpretasie van die Bybel is tot dusver meestal in terme van Nuwe-Testamentiese wetenskap ontwikkel met sporadiese pogings om dit in terme van Ou-Testamentiese wetenskap te ontwikkel..$^{2}$ In hierdie opvolgartikel word hierdie benadering tot die Bybelteks bedink - veral in terme van die metodologiese onderbou onderliggend aan Teologiese interpretasie van die Bybel as dissipline. ${ }^{3}$ Die eerste artikel getiteld, 'Die verhouding tussen Ou-Testamentiese wetenskap en Teologiese interpretasie van die Bybel: Handelinge 8:2640 as gevallestudie' (Viljoen 2017) het inleidende gedagtes rondom my eie verstaan van die definiëring van Teologiese interpretasie van die Bybel asook die verhouding tussen spesifiek OuTestamentiese wetenskap en Teologiese interpretasie van die Bybel ondersoek.

'n Gebrek aan goed ontwikkelde metodologiese oorwegings kortwiek egter Teologiese interpretasie van die Bybel. Met hierdie artikel word gepoog om 'n bydrae tot die ontwikkeling daarvan te lewer. Vir Meadowcroft (2013:7) sluit die nodige voorwaardes vir goeie teologiese interpretasie van die Bybel onder andere ook volgehoue metodologiese besinning in ${ }^{4}$ (kyk ook Green 2011:16-20). Verskeie pogings is reeds aangewend om die tekort aan te spreek, maar daar is baie ruimte vir die ontwikkeling van hierdie benadering tot die Bybelteks - veral in terme van die metodologiese onderbou onderliggend aan Teologiese interpretasie. ${ }^{5}$ Die doel van hierdie

1.Die doel van die artikel is om Teologiese interpetasie van die Bybel as dissipline aan te bied - 'n afsonderlike dissipline met sy eie fokus en skopus. Die dissipline het relatief onlangs ontstaan hoofsaaklik binne die konteks van ' $n$ Christelik-Amerikaanse perspektief met ' $n$ meer teologies konserwatiewe geneigdheid (hetsy postmodern of nie). Dit is gevolglik die perspektief wat, ten minste vir nou Teologiese interpretasie van die Bybel verteenwoordig. Die bedoeling hier is nie om 'n globale perspektief aan te bied van wat aan die gang is binne Ou-Testamentiese wetenskap as navorsingsveld nie, maar wat hier aangebied word, is beperk tot die ontwikkeling van die spesifieke dissipline Teologiese interpretasie van die Bybel.

2.Vir voorbeelde van Teologiese interpretasie binne die werkgebied van die Ou-Testamentiese wetenskap, kyk onder andere Vanhoozer (2008); Bartholomew, Bartholomew en Beldman (2012); verskeie bydraes in Green en Meadowcroft (2013).

3.Die skopus van hierdie artikel is nie die ontwikkeling van 'n Ou-Testamentiese teologie nie, maar' $n$ bydrae tot die ontwikkeling van die metodologiese onderbou van Teologiese interpretasie van die Bybel as ' $n$ afsonderlike dissipline wat die teologiese interpretasie van spesifieke Bybeltekste as oogmerk het. Die metodologiese oorwegings wat hier aangebied word, word met hierdie spesifieke taak in gedagte aangebied. Teologiese interpretasie van die Bybel is' $n$ eiesoortige dissipline wat in skopus en fokus verskil van Ou-Testamentiese teologie. Om hierdie rede word verskeie leidende Ou-Testamentiese teologieë as sodanig nie oorweeg en weergegee in die verwysing na onlangse navorsing nie.

4.Ander belangrike voorwaardes vir goeie Teologiese interpretasie is, volgens Meadowcroft (2013:7), heel waarskynlik geneig om in plek te val binne die gesprek tussen die onderskeie benaderings of perspektiewe waaruit Teologiese interpretasie gepraktiseer word, naamlik Christologiese- en/of Trinitariese benaderings; die geloofsreël en/of meer algemene nosie van tradisie; wanneer dit gemodereer word deur 'n teologie van die Skrif as die viva vox Dei; en wanneer die gesprek teen die agtergrond van diepliggende metodologiese besinning volgehou word.

5.Adam et al. (2006:8) noem dat dit ' $n$ fout sou wees om in die ontstaan van Teologiese interpretasie die ontstaan van 'n nuwe bybelse .Adam et al. (2006:8) noem dat dit ' $n$ fout sou wees om in die ontstaan van Teologiese interpretasie die ontstaan van ' $n$ nuwe bybelse die Skrif of hulle eiesoortige algemene uitgangspunte nie (kyk ook Green 2011:3). Carson (2011:187) wys ook daarop dat verskeie die Skrif of hulle eiesoortige algemene uitgangspunte nie (kyk ook Green 2011:3). Carson (2011:187) wys ook daarop dat verskeie
skrywers op diverse wyses oor Teologiese interpretasie skryf. Meadowcroft (2013:2) wys daarop dat praktisyns van Teologiese
interpretasie oor die algemeen verkies om eerder te dink in terme van ' $n$ perspektief of benadering as ' $n$ metodologie. Dit is egter belangrik om nadenke en die gesprek rondom metodologiese oorwegings ten opsigte van Teologiese interpretasie krities te assesseer 
artikel is om verskeie teologiese interpreteerders van die Bybel se metodologiese besinnings weer te gee en om in gesprek met hulle my eie verstaan van Teologiese interpretasie verder uit te bou. Drie meta-hermeneutiese aspekte word ondersoek $^{6}$ wat die breë metodologiese onderbou van Teologiese interpretasie van die Bybel uitmaak, naamlik metafisika, epistemologie en etiek ${ }^{7}$.

\section{Metodologiese onderbou van 'n hermeneutiek vir Teologiese interpretasie: Drie meta-hermeneutiese aspekte Metafisika}

Post-Aufkläring hermeneutiek neig om beperk te raak in 'n eksklusiewe fokus op een van die twee kompeterende sfere van menslike agentskap wat streng gedefinieer is in terme van immanente parameters, hetsy in terme van die teks as produk van ('n) menslike agent(e) of in terme van die leser as 'n objektiewe agent, vry van ander agente se invloed (Bowald 2007:371; 2010:167-168). Derhalwe word kontemporêre bybelse hermeneutiek tradisioneel bedryf in terme van die 'teks-leser'-teenstelling met menslike agentskap as fokus-kenmerk van albei: fokus op die teks sentreer menslike agentskap op die skep en samestelling van tekste terwyl fokus op die leser menslike agentskap op die verskeidenheid van leesaktiwiteite sentreer (Bowald 2010:167). Lombaard (2015:4) wys op die hoofkategorieë van verstaan in die onderskeie religieus-kulturele 'fases': geskiedenis in die moderne fase en taal in die postmoderne fase. Hermeneutiese benaderings wat op die teks fokus, neig in die rigting van hermeneutiese realisme, terwyl benaderings wat op die leser fokus, in die rigting van hermeneutiese idealisme neig. Die refleks-nadruk op menslike agentskap in terme van een van hierdie twee aspekte van die hermeneutiese proses is na my mening 'n weerspieëling van die 'teks-leser'-teenstelling, kenmerkend van post-Aufkläring hermeneutiek, met geskiedenis in die moderne fase wat op die teks fokus en taal in die postmoderne fase wat op die leser fokus. Nietemin, menslike agentskap is steeds die fokus-kenmerk van albei.

Verskeie hermeneute sien die oplossing tot sulke eenduidige of eksklusiewe fokusse wat 'n verskralende hermeneutiese effek het, verskillend. Vir Lombaard (2015:4) lê die oplossing nie in die omseiling van die impulse van moderne en post-moderne hermeneutiek nie, maar eerder in 'n direkte ondersteuning daarvan met die oogmerk om meer in die teks raak te sien en derhalwe meer aan die leser te kan lewer, naamlik 'n geloofservaring.

6.Vanhoozer ([1998] 2009) se drieledige skema vir nadenke oor die metodologiese onderbou van teologiese hermeneutiek word hier gevolg.

7.Ek moet toegee dat ek myself veel eerder as 'n Bybelwetenskaplike as 'n filosoof sien. Die gevolg is dat ek die konsepte metafisika, epistemologie en etiek vanuit ' $n$ teologiese perspektief benader. Hierdie konsepte is nie net vir filosofie van belang nie, maar ook vir ander dissiplines. Ek is oortuig dat dit ' $n$ ruimte verteenwoordig, nie, maar ook vir ander dissiplines. Ek is oortuig dat dit ' $n$ ruimte verteenwoordig,
wat Van Huyssteen (1999; 2006) konvergensie noem, waar teologie en/of Bybelwetenskappe en filosofie gemeenskaplike vraagstukke betrek. Hierdie Bybelwetenskappe en filosofie gemeenskaplike vraagstukke betrek. Hierdie
konsepte word dus betrek sonder die voorwendsel dat ek'n filosoof is en sonder om my teologies-Bybelwetenskaplike perspektief of identiteit prys te gee.
Ricoeur, in sy nadenke oor die bydrae van hermeneutiese filosofie tot bybelse eksegese, sien teologie as'n hermeneutiese oefening. Nader in dissipline aan eksegese as aan filosofie, is teologie 'n nie-spekulatiewe interpretasie van die begrondende diskoers in die Ou- en Nuwe Testamente sonder die voordeel van 'n rasionele fondament waarop die onderneming gebaseer word (Wallace 1995:23). Vir Ricoeur hou die partikulariteit van bybelse hermeneutiek primêr met die verwysende aard van die Bybelteks en spesifiek die Godverwysing verband (Moyaert 2014:28). Die God van die Bybel is vir Ricoeur (1995a:227-228) ook op geen wyse analoog tot 'n filosofiese konsep nie, ${ }^{8}$ omdat dit die totale konteks van die verskeidenheid van genres veronderstel wat die realiteit van God verskillend be- of getuig. ${ }^{9}$ Vir Ricoeur hou bybelse diskoers dus met ' $n$ realiteit buite taal verband - 'n ekstra-linguistiese realiteit wat in taal tot uitdrukking kom (Moyaert 2014:30). Ricoeur bedink 'n bemiddeling tussen twee alternatiewe. Die een alternatief is 'n fokus wat op die teks gesentreer is - óf in die outeursintensie óf die hipostasiëring van die teks as 'n outeurlose entiteit (Wallace 2000:305-306). Die ander alternatief is fokus wat op die leser gesentreer is - in sy of haar objektiwiteit wat die teks as objek (eerder as subjek) benader (Ricoeur 1995b:262).

Bogenoemde is verskeie hermeneutiese pogings om die moeilike balans tussen hermeneutiese realisme en hermeneutiese idealisme te vind om so die 'teks-leser'teenstelling te navigeer. Nogtans is menslike agentskap steeds die fokus-kenmerk van albei. Verskeie teologiese interpreteerders verskuif egter die fokus na Goddelike agentskap en dit is hulle siening wat, na my mening, die grootste bydrae kan maak tot nadenke rondom die metodologiese onderbou van Teologiese interpretasie van die Bybel.

Die eerste bydrae wat hier ter sprake kom, is díe van Vanhoozer. God se trinitariese kommunikatiewe handelinge is vir Vanhoozer ${ }^{10}$ ([1998] 2009:457) die paradigma en nie bloot 'n illustrasie nie van alle egte kommunikasie -die stuur sowel as ontvang van 'n boodskap. Die drie-enige God is die toonbeeld van kommunikatiewe agentskap: die kommunikatiewe agent wat God se woord uiter, beliggaam en gestand doen. Albei posisies in die hermeneutiese dispuut, hermeneutiese realisme sowel as hermeneutiese idealisme, ${ }^{11}$ beskuldig die ander van afgodery - om valse konstrukte of beelde van God daar te stel (Vanhoozer [1998] 2009:457). Gedeeltelik is idealisme natuurlik reg in dat subjektiwiteit noodwendig ' $n$ rol in interpretasie speel - as mens sien ons tekste en die wêreld nie soos God dit sien nie, maar deur ons beperkte en feilbare hermeneutiese

8.Selfs nie die Middeleeuse-filosofiese konsep van wese of die Heideggeriaanse daarwees van Dasein nie (Ricoeur 1995a:227)

9.God se naam is terselfdertyd dit wat die bybelse diskoers in al die variëteite daarvan bymekaar hou asook die verdwynpunt wat die geheim van God se 'in Godself wees' bewaar (Moyaert 2014:48)

10.Bowald (2007) toon aan hoedat Vanhoozer se latere hermeneutiese insigte die deïstiese tendense van sy vroeëre denke oorkom deur' $n$ groter beklemtoning van die huidige agentskap van God.

11.Vir Vanhoozer ([1998] 2009:27) kan hierdie twee posisies in terme van die hermeneutiese en die hermetiese beskryf word. Dekonstruksie staan vir hom in die hermetiese tradisie in soverre dit ' $n$ alternatief op hermeneutiek verteenwoordig wat die moontlikheid van literêre kennis ontken. 
raamwerke. ${ }^{12}$ Vir Vanhoozer ([1998] 2009:458) is sommige hermeneutiese raamwerke - in besonder die literêre raamwerke of genres van die Bybel - meer deurlaatbaar vir die realiteit (soos God dit sien) as ander. Dit is in ooreenstemming met die Christelike verstaan van die openbarende aard van die Bybel. Die groot bydrae van postmoderne hermeneutiek en literêre kritiek is die bewustheid dat kennis van tekstuele betekenis nooit absoluut is nie. Desnieteenstaande is dit vir ' $n$ leser moontlik om voldoende literêre kennis van die teks te bekom. Die leser word met ' $n$ bemiddelde onmiddellikheid gekonfronteer wanneer hy of sy lees - die gesig of stem van 'n ander (Vanhoozer [1998] 2009:458-459). Vir Vanhoozer is die ander die outeur.

Teenoor die 'Nuwe kritiek' (uiteengesit deur Wimsatt \& Beardsley 1954) wat literatuur met die teks self as fokus benader, los van die oorsprong of effek daarvan, sien Vanhoozer ([1998] 2009:459) die teks as kommunikatiewe handeling, gekenmerk deur intensie, illokusie en doeltreffendheid. Hy ontgin, met behulp van Jean-Luc Marion (1991) se analogie van die ikoon, die Nuwe kritiek se konsep van die verbale ikoon as 'n positiewe apologetiek teenoor die verstaan van die teks as 'n afgod. Hy pas die analogie van die ikoon toe op teologie en die gedagte om God te bedink in terme van 'n metafisiese realiteit (Vanhoozer [1998] 2009:468). Hy is van mening dat ekstreme lesersrespons metodologieë van die teks 'n afgod maak waar die skep van betekenis eksklusief aan die leser toegeskryf word - 'n spieël waarin die leser net hom- of haarself gereflekteer sien (Vanhoozer [1998] 2009:460). Teenoor die projeksie van die leser op die teks as afgod, is 'n ikoon 'n openbaring - in die ikoon ${ }^{13}$ ontmoet die leser 'n ander. ${ }^{14}$ 'n Ikoon vestig nie die aandag op homself nie, maar reik verby die oppervlak en lê dít bloot wat anderkant die oppervlak is, naamlik die transendente. Die verskil tussen 'n afgod en 'n ikoon is nie die onderskeid tussen twee objekte nie, maar hoe dieselfde objek op verskillende maniere benader word (Vanhoozer [1998] 2009:460). Die Bybel is 'n verbale ikoon met die taak van interpretasie om verby (of oor) die leser se self te kom deur aandag aan die vorm van 'n literêre handeling te skenk ten einde ' $n$ beliggaamde intensie teë te kom. Die Bybelteks bemiddel 'n persoonlike teenwoordigheid in die vorm van 'n 'stem'. Om aan die hipostases van 'n visuele of verbale ikoon aandag te gee, hoef nie, volgens Vanhoozer ([1998] 2009:161), die substansiële teenwoordigheid van 'n persoon te impliseer nie, maar slegs ' $n$ persoon se intensionele teenwoordigheid.

Die tweede bydrae wat hier ter sprake kom, is díe van Bowald. Na my mening kan Vanhoozer se fokus op die outeur uitgebrei word met Bowald se gedagte dat die karakter van God as kommunikatiewe agent die fundamentele hermeneutiese horison uitmaak vir Teologiese interpretasie.

12.Derhalwe'n hermeneutiek van suspisie ten opsigte van alle interpretasie - ook my eie - veral as dit 'n selfversekerde hermeneutiek is (Vanhoozer [1998] 2009:458).

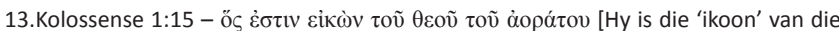
onsigbare God].

14.Die naam van God het ' $n$ subverserende funksie wat alle taal tot by die limiet dra en so die risiko van afgodery beperk (Moyaert 2014:48).
Vir Bowald (2007; 2010) lê die oplossing daarin dat die noodwendige en ingewikkelde verband tussen Goddelike en menslike agentskap in 'n hermeneutiek vir Teologiese interpretasie dieper bedink word (Bowald 2007:367-368). Derhalwe, stel hy voor dat die metafisika van Christelike hermeneutiek eerder onder die rubriek van die leer van verlossing bedink word (Bowald 2007:373; 2010:167). Die ontologie van die kanon het sy oorsprong (is geïnisieer van buite die geskape realm) vanuit die lewe van die drie-enige God $^{15}$ (Bowald 2010:167). As gevolg van hierdie metafisiese grondslag bestaan die tendens in kontemporêre Christelike hermeneutiese paradigmas om die lees van die Bybelse teks te bedink onder die rubriek van die skeppingsleer. Hierdie tendens het, volgens Bowald (2007:367-368), 'n deïstiese geneigdheid tot gevolg waarin die handelinge van God beperk word tot die skep en onderhouding van 'n stabiele sisteem van menslike spraakhandelinge, gegrond op die taalvermoë van die mens as imago Dei. 'n Hermeneutiese paradigma wat rekening hou met die huidige handelinge van God en wat verder gaan as die aanvanklike daarstel en stabiliserende effek van God se aktiwiteit, is nodig en noodsaaklik (Bowald 2007:368). Vir hom is Teologiese interpretasie eiesoortig ten opsigte van twee aspekte: Die primêre outeur van die Bybel is voortdurend beskikbaar vir die leser; en hierdie outeur is God (Bowald 2010:168). Bowald (2010:173) gebruik 'n studie van retoriek - drie aspekte van die retoriese moment - om te verstaan hoe die karakter van die kommunikerende agent (ethos) die boodskap (logos) se ontvangs beïnvloed, asook die respons (pathos) daarop. Met sy teologies-retoriese hermeneutiek stel hy Goddelike etos [karakter] as die fundamentele hermeneutiese horison waarbinne die Bybel as Skrif gelees word (Bowald 2010:176).

Vanhoozer beweeg in hierdie rigting met sy gebruik van die ontluikingsteorie met die konsepte supervensie (supervenience) en ontluikende eienskap (emerging property) om die teologiese betekenis van 'n teks te beskryf. Alhoewel hy homself aanvanklik nog in sy denke tot menslike outeursintensie as die ontluikende eienskap beperk, met die intensie van die menslike outeur wat die oorsprong en kousaliteit van die teks verantwoord, gaan hy later verder om die fenomeen van die kanon en God se agentskap in terme van outeurskap te beskryf (sien ook Bowald 2007:373-380). Die kanon as geheel is vir hom die ontluikende eienskap wat 'n hoër orde fenomeen karakteriseer en wat voortkom uit die laer vorms (die individuele Bybelboeke) waaruit dit opgemaak word. ${ }^{16}$ Hierdie hoër orde fenomeen bereik so 'n vlak van organisatoriese kompleksiteit dat dit nuwe eienskappe vertoon en gevolglik nuwe kategorieë benodig om beskryf te

15.Dit is nietemin ook terselfdertyd ' $n$ vennootskap tussen die Goddelike outeur en menslike outeur(s), redaktor(s) of kanoniseerders (Bowald 2010:181).

16.Vanhoozer ([1998] 2009:249) gee drie ander voorbeelde van supervensie: eerstens, Biologie: ' $n$ sel is 'n komplekse fenomeen wat ontluik vanuit die laer orde infrastruktuur van molekules en atome wat dit onderlê en derhalwe die nuwe kategorieë van biochemie benodig om beskryf te word; tweedens, Sielkunde: geestelike eienskappe is afhanklik van die biologiese infrastruktuur (fisiese geestelike eienskappe is afhanklik van die biologiese infrastruktuur (fisiese eienskappe) wat dit onderle. Sonder hoer orde kategoriee sou die beskrywing van geestelike eienskappe (soos denke, bewussyn en persoonlikheid) onbeskryfbaa bly, aangesien hierdie state onverminderbaar is tot die eienskappe van die fisies staat van die substrata wat dit onderlê; en derdens, Taal: parole as spraakgebeure, n spesifieke boodskap met verwysende intensie, is die ontluikende eienskap wa deur lingue, die interne organisering van die boodskap in woorde en sinskonstruksie onderlê word (kyk ook Ricoeur 1976:20) 
word (Vanhoozer [1998] 2009:249). Vir hierdie rede kan die kanon as die resultaat van Goddelike agentskap (die kanon as woord van God) met behulp van die teorie van ontluiking in terme van 'n hoër orde fenomeen met nuwe ontluikende kategorieë beskryf word. Ter wille van bondigheid sal hier nie op die kompleksiteit ('n kompleksiteit wat'n hermeneutiek vir Teologiese interpretasie in berekening sal moet bring) van die verband tussen menslike en Goddelike agentskap ten opsigte van outeurskap in terme van die kanon ingegaan word nie. Die punt wat eerder hier gemaak word, is dat Goddelike agentskap en die kanon in terme van die teorie van ontluiking bedink kan word sodat God se karakter as die fundamentele hermeneutiese horison geneem word vir 'n hermeneutiek vir Teologiese interpretasie wat die Bybel as woord van God lees. So kan Teologiese interpretasie erns met God se agentskap in die hermeneutiese proses maak sonder om menslike agentskap, wat die tradisionele fokus-kenmerk van die meerderheid van post-Aufklaring hermeneutiese modelle uitmaak, te negeer.

As Teologiese interpretasie Goddelike agentskap en die kanon in terme van die teorie van ontluiking bedink, en God se karakter as die fundamentele hermeneutiese horison neem waarbinne die Bybel as woord van God gelees word, wat maak ' $n$ hermeneutiek vir Teologiese interpretasie met nonen post-fondamentalistiese hermeneutiese benaderings se vraag na die aard van kennis? Dit bring ons by die verkenning van epistemologiese oorwegings van 'n hermeneutiek vir Teologiese interpretasie.

\section{Epistemologie}

\section{Teofondamentalisme}

Treier (2008:18) merk op dat Barth tot 'n groot mate kontemporêre inspirasie verskaf vir Teologiese interpretasie. Alhoewel hy nóg die enigste nóg 'n statiese model van Teologiese interpretasie verteenwoordig (Treier 2008:18), sien verskeie teologiese hermeneute 'n gebalanseerde epistemologiese posisie in sy denke. Dus ontgin verskeie voorstanders van Teologiese interpretasie sy denke (kyk onder andere Bowald 2007; Diller 2007:273-278; Treier 2008:14-20). Barth se denke is nie die eksklusiewe voedingsbron vir 'n besinning rondom die metahermeneutiese aspekte van Teologiese interpretasie nie, maar verteenwoordig ' $n$ produktiewe vertrekpunt vir die onderneming (Treier 2008:17-20).

Barth begin by die voorveronderstelling van openbaring en is tot die realiteit of aktualiteit (Wirklichkeit) van God verbind (Diller 2007:278). Ten opsigte van teologiese kennis is sy bekende reël dat die ratio essendi [metafisiese basis] die ratio cognoscendi [epistemologiese gronde] voorafgaan en beheer; God se aard - wie God is en wat God doen - bepaal die aard en vorm van ons kennis oor God (Bowald 2007:367). Opsommend verwoord Diller (2007:278) Barth se posisie soos volg: Christelike teologie is verbind tot die objektiewe realiteit van God wat as die Woord wat mens geword het, Godself aan die kerk bekend maak deur menslike ervarings van realiteit, maar erken die feilbaarheid van menslike kennis - kennis van God wat altyd slegs deur die voorafgaande, selfgewende handelinge van God toeganklik deur ervaring is. Daarom stel Diller (2007) op grond van Barth se epistemologiese besinnings 'n teofondamentalistiese epistemologie voor. Wanneer Barth in terme van die voordele en nadele vir teologie van onderskeidelik realisme en idealisme dink, begin hy by realisme, aangesien ' $n$ mate van realisme onvermydelik is wanneer die onderwerp van denke of spreke God is (Diller 2007:276). Die gevaar van'n onkritiese realisme is dat die realis veronderstel dat kennis van God direk uit die data van gegewe ervaring, hetsy subjektief of empiries, gelees kan word. Daarteenoor is die vertroue waarmee kennis van God bekom word, vertroue in God se selfgewende handelinge wat anders as realisme se vertroue in God se gegewendheid is (Diller 2007:276). Teologiese interpretasie gaan dus uit van ' $n$ fondament, maar dit is nie die selfversekerde fundamentalisme, gegrond in Cartesiaanse rasionalisme, Lokciaanse empirisisme of die transendentale logika van die Duitse idealisme nie (vgl. Diller 2007:274-275). Idealisme, aan die ander kant, temper 'n onkritiese realisme omdat dit die probleem erken, naamlik om neutrale gronde vir kennis buite die self van die hermeneut te verseker (Diller 2007:277). Die feit dat kennis van God 'van onder' 'n menslike onmoontlikheid is, verander egter nie die feit dat God dit vir mense 'van bo' moontlik maak om God te ken nie. Derhalwe hoef teologiese kennis nie in 'n idealisme te verval nie (Diller 2007:277). Volgens Diller (2007:289) is geloof vir Barth nie 'n riskante menslike handeling of waagstuk gegrond in die onderneming van die teoloog nie; dit is eerder 'n gawe van God gegrond in geloof wat deur die openbarende handeling van God verseker word. Hy (Diller 2007:289) voeg by dat die Christelike idee van God nie 'n selfregverdigende fondasie uitmaak nie; God self is die enigste selfregverdigende fondasie vir kennis van God.

Slegs 'n teofondamentalistiese epistemologie vermy die tradisionele hermeneutiese slaggate - fideïsme aan die een en skeptisisme aan die ander kant, terwyl dit epistemiese nederigheid behou (Diller 2007:271). Non-fondamentalisme navigeer dikwels nie die gevaar van fideïsme nie, terwyl post-fondamentalisme 'n geslote feilbare menslike sisteem veronderstel wat vir 'n eksterne bron van waarborg geslote bly en, derhalwe, enige oorwegings van ' $n$ 'van bo' nosie van geopenbaarde kennis verwerp (Diller 2007:290). Teologiese interpretasie dra die waarmerk van nederigheid gesetel in teofondamentalisme se bewustheid dat die feilbaarheid van menslike kennis onfeilbaar oorbrug word deur die openbarende handelinge van God wat menslike proposisies omvorm in voldoende draers van waarheid (vgl. Diller 2007:293).

\section{Hermeneutiese rasionaliteit, genre en die aard van literêre kennis}

Hermeneutiese rasionaliteit is die strewe na literêre kennis. In sy beskrywing van die objek van literêre kennis, reserveer Vanhoozer ([1998] 2009:322) die term interpretasie vir pogings om literêre handelinge te verstaan. Wat ' $n$ interpreteerder van 'n teks beskryf, is die teks as 'n literêre handeling (Vanhoozer [1998] 2009:324). Die epistemologiese veronderstelling, 
onderliggend aan Teologiese interpretasie, is dat literêre kennis vir die hermeneut toeganklik is. Alhoewel absolute literêre kennis nie moontlik is nie, is voldoende literêre kennis wel 'n hermeneutiese moontlikheid (Vanhoozer [1998] 2009:300). Hierdie epistemologiese veronderstelling is gegrond in die deursigtigheid van die Skrif wat nóg 'n absolute waarde, nóg 'n abstrakte eienskap van die Bybelteks is. Dit is 'n spesifieke funksie relatief tot die bepaalde doel van die Skrif: getuienis aangaande Christus. Dit gaan nie soseer oor die voor-die-hand-liggendheid van die Bybel as oor die doeltreffendheid daarvan nie. Die Bybel is duidelik genoeg om die kommunikatiewe handeling doeltreffend te lewer. Dit beteken nie dat die leser alles sal weet wat daar is om te weet met betrekking tot die teks nie, maar sy of hy sal genoeg weet om 'n verantwoordelike respons te kan maak ten opsigte van die onderwerp waaroor die teks handel (Vanhoozer [1998] 2009:317). Wat uiteindelik op die spel is in die epistemologie van literêre kennis is bybelse outoriteit die vermoë van die Bybelteks om die leser aan te spreek en te transformeer (Vanhoozer [1998] 2009:314). Hermeneutiese rasionaliteit, alhoewel nie absolute kennis nie, lewer tog wel kennis op omdat ons paradigmas of deskriptiewe raamwerke nie noodwendig blokkasies tot verstaan hoef te verteenwoordig nie, maar ook voorwaardes wat weliswaar nie absolute nie, maar voldoende verstaan moontlik maak. Voldoende kennis behels hier insig in die kommunikatiewe doeleindes van die teks met die oog op 'n respons daarop (Vanhoozer [1998] 2009:334-335). Om op die teks te reageer, is om toe te laat dat die kommunikatiewe doeleindes wat dit voor oë het, bereik word.

Om die kommunikatiewe handeling van die teks te beskryf, moet egter nie met 'n beskrywing van óf die oorspronklike situasie waarin die teks ontstaan het (die histories kritiese geneigdheid) óf van die daaropvolgende belang van die teks (die geneigdheid van lesersrespons metodologieë) verwar word nie (Vanhoozer [1998] 2009:327). Marshall (1992:176) toon aan dat Frei ook aandui dat 'n teologiese lees die lees van die teks self is en nie die lees van 'n bron onderliggend aan die teks soos die histories kritiese geneigdheid is om tekste te lees nie. Kennis oor die teks is nie dieselfde as kennis van dít waaroor die teks handel nie (Vanhoozer [1998] 2009:282). Binne die hermeneutiese raamwerk van die teks as kommunikatiewe handeling is die primêre taak van interpretasie om die 'wat', 'hoekom' en 'waarom' van wat geskryf is eerder as die sekondêre vrae 'wie', 'wanneer en 'waar' dit geskryf is (wat nietemin ook help om die primêre oorwegings te verstaan), te beskryf.

Hermeneutiese rasionaliteit (die strewe na literêre kennis) word die beste in terme van abduktiewe afleidings (eerder as deduktiewe of induktiewe redenasies) beskryf: Die hermeneut se oogmerk is literêre kennis - 'n verduideliking van hoe en hoekom die teks is soos wat dit is en waaroor die teks handel. Hy of sy kom tot hierdie gevolgtrekking deur intensies aan die outeur van die teks toe te skryf wat die teks kan verantwoord in sy dele en in sy geheel. Kritiese interpretasie formuleer hipoteses oor wat die outeur gedoen het deur aandag aan sy of haar woorde te gee. ${ }^{17}$ Dus, die geldigheid van die interpretasie is nie afhanklik daarvan dat die bestaan van die outeur se intensie bewys word nie, maar die hermeneut illustreer die verklarende vrugbaarheid van sy of haar abduktiewe afleiding of hipotese deur vrae oor die teks te vra waartoe sekere beskrywings van die literêre handeling moontlike antwoorde verteenwoordig. In die konteks van hermeneutiek bied die teorie of hipotese maksimum verstaan as dit genoegsaam beskryf wat op elk van die belangrike vlakke van die handeling gebeur (op die lokusionêre, illokusionêre en literêre vlakke van die teks). Die beste interpretasie moet die literêre handeling dus op so 'n wyse beskryf dat dit die leser in staat stel om meer oor die teks te verstaan as wat ander interpretasies moontlik maak. Die beste interpretasie hoef ook nie ' $n$ absolute een te wees nie, maar kan verbeter en beoordeel word in terme van die oplossings wat dit bied om hermeneutiese probleemvrae oor die teks op te los (Vanhoozer [1998] 2009:334).

Die aanspraak dat diskoers oor iets handel, word in die nosie van kommunikatiewe handeling geïmpliseer. Verstaan in hierdie konteks het dus te doen met die kognitiewe kontak van die hermeneut met dít wat die outeur in die teks gedoen het asook met dít waaroor die teks handel (Vanhoozer [1998] 2009:324). Vanhoozer ([1998] 2009:342) dui aan dat genre as maniere van beteken die hermeneut help om die verskeidenheid van kognitiewe kontak met realiteit wat in die onderskeie genres gemaak word, te onderskei. Dit is egter nie tot empiriese verwysing beperk nie. Volgens Bakthin (in Vanhoozer [1998] 2009:342) is genre meer as kommunikatiewe strategieë met diverse illokusionêre krag om ander mense deur middel van woorde te betrek, maar omdat dit visievormend is, verteenwoordig dit ook 'n variëteit van kognitiewe strategieë met diverse maniere om die wêreld te verbeeld en so betrekking op realiteit te hê. Genre is dus 'n modus van ervaring van en denke oor die wêreld. Elke genre maak ' $n$ unieke manier van nadenke oor en ervaring van die wêreld moontlik. Dit het baie raakpunte met paradigmas wat sekere aspekte van die realiteit verhelder. Dit het ook baie raakpunte met metafore wat, soos Ricoeur ([1977] 1994; 1978) aangetoon het, onontbeerlike kognitiewe instrumente is. Vir Ricoeur (1977:15) bemiddel die verskeie vorms van bybelse diskoers of genres openbaring op 'n onverminderbare manier - sodanig dat, indien die vorm van die teks versaak word, ${ }^{18}$ die inhoud ook verlore gaan omdat genre meer is as ' $n$ klassifiseringsinstrument van literêre vorms; dit is kognitiewe instrumente vir die generering van wêreldbeskouings. Daarom is die soort literêre kennis wat 'n teks bied, afhanklik van die soort literatuur of die genre van die teks (sien ook Moberly 2011:173). Die literêre vorm van 'n teks is nie toevallig nie, maar noodsaaklik ten opsigte van die inhoud van die teks (kyk ook Ricoeur in Reese [1979] 1990:385).

17. Die Engels soos Vanhoozer ([1998] 2009:334) dit beskryf, is treffend: 'what did the author intend in tending to his or her words'. Hierdie twee aspekte van 'n literêre handeling is na my mening vergelykbaar met Ricoeur se verstaan van taal as handeling is na my mening vergelykbaar met Ricoeur se verstaan van taal as onderskeidelik lingue en parole. Lingue of die 'wat gesê is' (what is said) is vergelykbaar met Vanoozer se 'aandag gee aan die outeur se woorde' (tending to his or her words). Parole of die 'waaroor dit gesê word' (about what it is said) kan vergelyk word met Vanhoozer se 'wat die outeur doen' (what the author intend) (vgl. Reese [1979] 1990:386-387; kyk ook; Viljoen 2015:4; Viljoen \& Venter 2013:2)

18.Soos in die geval van ontmitologisering (Vanhoozer 2010:13-23). 
Dat genre 'n wêreldbeskouing of perspektief op realiteit is, ondermyn nie die moontlikheid van egte verwysing nie slegs die mite van 'n totale verteenwoordiging van realiteit. Geen genre kan die volle realiteit beskryf nie, maar is ' $n$ beperkte deskriptiewe raamwerk. Genre is soos 'n kaart wat verskeie aspekte van realiteit belig en bied in sommige gevalle ons enigste toegang daartoe - weliswaar realiteit 'onder beskrywing', maar nogtans realiteit (Vanhoozer [1998] 2009:342). In kritiese realisme is daar 'n verband tussen die verstaan van realiteit en die verstaan van tekste ten opsigte van die deskriptiewe verwysingsraamwerk (of paradigma, of spesifieke hermeneutiese skema) waarmee ons realiteit of die teks benader. Dit is nie dat ons paradigmas die realiteit konstrueer nie, maar dat sekere aspekte van die realiteit slegs na vore tree of aan die lig kom onder sekere deskriptiewe verwysingsraamwerke (Vanhoozer [1998] 2009:232). Met ander woorde, terwyl kritiese realisme tot die beginsel van bepaalde betekenis verbind is, onafhanklik van die observeerder van realiteit of die leser van ' $n$ teks, is dit nietemin ook oop vir die aanwend van verskeie deskriptiewe verwysingsraamwerke om verskeie aspekte van realiteit of die teks te belig. Hierdie aspekte van realiteit sou onbeskryfbaar wees sonder die leser se paradigmas of verwysingsraamwerk en net gedeeltelik beskryf kon word deur enige enkele paradigma of verwysingsraamwerk (Vanhoozer [1998] 2009:322). Alhoewel ons realiteit of die teks noodwendig benader vanuit ' $n$ hermeneutiese skema of paradigma of spesifieke deskriptiewe verwysingsraamwerk wat ons kennis beperk en voorlopig maak, kan verstaan van die realiteit of die betekenis van die teks waartoe ons toegang kry deur middel van ons verwysingsraamwerk steeds ware kennis wees (Vanhoozer [1998] 2009:323).

Genre is vir Vanhoozer ([1998] 2009:337-338) 'n vorm van sosiale gedrag wat deur reëls gereguleer word en dus kommunikatiewe bevoegdheid vereis. Vir hom is literêre genre 'n taalspel en die hermeneut se taak is om te bepaal watter spel gespeel word, byvoorbeeld geskiedenis, kronologie, profesie, gelykenis, ensovoorts. Hy is oortuig dat literêre genres kommunikatiewe handelinge van 'n hoër orde is en op 'n hoër vlak van organisatoriese kompleksiteit bestaan. Net soos ons linguistieke bevoegdheid ontwikkel om te verstaan hoe woorde in alledaagse kontekste gebruik word, net so kan (en moet) ons literêre bevoegdheid ontwikkel om die verskeidenheid van tekste te verstaan en hoe woorde binne die konteks van onderskeie genres gebruik word. Dit het dus te doen met 'generiese rasionaliteit'; nie generies in die sin van algemeen nie, maar in die sin van 'kenmerkend van 'n spesifieke literêre tipe'. Die reëls wat 'n bepaalde literêre genre reguleer, is nie ekstrinsiek aan die teks nie, maar word in die teks beliggaam. Verstaan het te doen met die aanleer van hierdie reëls tot op die punt dat hulle gevolg kan word.

Skryf sowel as lees behels dus 'kommunikatiewe bevoegdheid': die praktiese vaardigheid of kundigheid om grammatikale en generiese reëls te verstaan. Soos Wittgenstein (1958) tereg uitgewys het, hou taalspeletjies met vorms van lewe verband. Soos geen enkele taalspel die wese van taal verteenwoordig nie, so verteenwoordig geen enkele vorm van lewe die wese van die lewe nie. As woorde inderdaad soos gereedskap is, soos Wittgenstein dit stel, kan genre, volgens Vanhoozer ([1998] 2009:338), moontlik beskou word as die projekte waarop hierdie gereedskap aangewend word. Om te sê dat tekste deur konvensie gereguleer word, is nie om te sê dat ons konsep van realiteit bloot konvensioneel is nie. Soos met die keuse tussen realisme en idealisme moet 'n digotomie vermy word: woorde en die wêreld kom enersyds nie net op één manier ooreen nie en andersyds kom dit ook nie op géén manier ooreen nie. Daar is dus 'n meervoudigheid van maniere waarop die verband tussen woorde (van 'n teks) en die wêreld (wat vrwys word) uitgedruk word, wat 'n verskeidenheid van genres tot gevolg het. Elke genre vertoon 'n eie verband tussen woord en wêreld. Die diversiteit van bybelse genres binne die kanon as die woord van God het 'n tweevoudige voordeel: die Skrif kan verskeie aspekte van realiteit betuig of beskryf en dit kan die leser op verskeie maniere aanspreek (bv. kognitief, emotief of in terme van die leser se wil) (Vanhoozer [1998] 2009:349).

'n Verskeidenheid van literêre genres betrek die realiteit op 'n verskeidenheid van maniere. Hier word onderskei tussen 'n letterlike interpretasie wat met 'n teorie van betekenis as verwysing werk (fundamentalisme sowel as historiese kritiek $)^{19}$ teenoor 'n literêre interpretasie wat lees vir die literêre betekenis en werk met 'n teorie van betekenis as kommunikatiewe handeling. Teologiese interpretasie het voldoende literêre kennis ten doel - kennis wat, onder andere, afhang van die mate waarin die leser se hermeneutiese bevoegdheid gekultiveer is. Die hermeneutiese proses van die bemiddeling van die realiteit waarvan die teks getuig en die interpretasie van die belang van die teks word nie net deur korrekte metodologie bepaal of gewaarborg nie, maar word ook bepaal deur wat Vanhoozer ([1998] 2009:367-369) die korrekte interpretatiewe deugde noem. Dit bring ons by die etiese oorwegings van 'n hermeneutiek vir Teologiese interpretasie.

\section{Etiek}

Teologiese interpretasie ondersoek, onder andere, hoe gelowiges en die kerk as geloofsgemeenskap 'n respons kan maak op die Bybelteks. Die unieke aard van die Bybel maak unieke aansprake op die leser (Bowald 2010:167). Omdat die soort respons wat die Bybel uitlok meer veeleisend is as ander literatuur, is die respons op die teks nie net 'n epistemologiese taak nie, maar ook 'n etiese en inderdaad geestelike taak (Vanhoozer [1998] 2009:335). Die Drie-eenheid wat ons hermeneutiese sirkels en praktyke daarstel en onderhou, neem dit ook in besit om dít wat waar, welvoeglik en goed is uit God se perspektief te bevestig en dít wat verdraai geraak het as gevolg van die sondeval, te hervorm of te transformeer (Bowald 2010:182).

Adam et al. (2006:11) wys daarop dat die etiese handelinge van die hermeneut vir bybelse interpretasie binne die

19.Daarom hoef alle dele van die Skrif nie as feitlik waar beskou te word in die sin van modernisme se historiese en empiriese kriteria nie, maar is daar ruimte vir die konseptualisering van literêre waarheid. 
werkruimte van Teologiese interpretasie baie belangrik is (kyk ook Briggs [2010] 2012). Dit behels etiese oorwegings regdeur die hermeneutiese proses: etiese oorwegings in verband met hermeneutiese metodes, maar ook oorwegings in verband met deurleefde, beliggaamde interpretasie van die Bybel. Hierdie deurleefde, beliggaamde hermeneutiek beïnvloed die hermeneut se akademiese en tegniese analises van die Bybel. Dit behels, onder andere, die soort lewenswyse wat die hermeneut voorberei en in staat stel om die Bybel geloofwaardig te interpreteer - 'n lewe wat getuig van grondige bybelse interpretasie asook wat uitdrukking gee aan die lof van God in aanbidding (Adam et al. 2006:11).

Die moraliteit van literêre kennis vereis nederigheid sowel as ywer. Hermeneutiese balans behels dat kennis met nederigheid gebalanseer word (Vanhoozer [1998] 2009:462). Twee hermeneutiese verantwoordelikhede balanseer mekaar:

- die negatiewe verantwoordelikheid om nie jou epistemiese greep te oorskry en op kennis aanspraak te maak van wat onkenbaar is nie; dus nederige bewustheid van beperkinge;

- die positiewe verantwoordelikheid om jou in te span om te wete te kom wat wel kenbaar is - om sonder luiheid te delf vir die gegewens van die teks.

Die moraliteit van literêre kennis vereis verder nog ook 'n balans tussen skeptisisme sowel as oortuiging. Lesers wat trots is op hulle interpretasies - konserwatiewe fundamentaliste sowel as liberale postmoderniste - loop die risiko om die teks te bemeester en hulle kommentaar op die teks te verhoog tot 'n status bó die van die teks (Vanhoozer [1998] 2009:463). Teologiese interpretasie, gegrond in 'n kritiese realisme, is getemper deur die postmodernisme se aanspraak op groter hermeneutiese nederigheid en hoef nie in die slaggat van hermeneutiese afgodery te trap nie. Met behulp van 'n gesonde verstaan van die gegewenes van kommunikatiewe agentskap hoef lesers ook nie in hermeneutiese skeptisisme te verval nie.

Nederigheid is wat die leser op die teks laat wag eerder as om dit te bemeester. Die betekenis en belang van ' $n$ teks is nooit die besit van die leser nie; dit is eerder 'n gedeeltelikvervulde (eskatologiese) belofte - die nodige teengif vir trotse of hoogmoedige interpretasies. Alhoewel absolute kennis nie ons besit is nie (die 'nog nie' van eskatologie), is voldoende kennis wel tot ons beskikking (die 'alreeds' van eskatologie of gerealiseerde epistemologie). Daarom kan Teologiese interpretasie tekste met die nodige moed van (Christelike) oortuiging interpreteer (Vanhoozer [1998] 2009:465-466).

Die deugde van nederigheid maak drie bydraes in terme van die meta-hermeneutiese oorwegings onderliggend aan Teologiese interpretasie:

- Metafisies: die besef dat lesers nie skeppers van betekenis is nie maar ontvangers daarvan, maak die leser meer realisties oor die doelwitte en mikpunte van hermeneutiek.
- Epistemologies: kritiese rasionaliteit erken die leser se feilbaarheid - trouens ook dié van die skrywer - maar ons vertroue in die moontlikheid om die Bybel te verstaan, is nie in menslike taal(vermoëns) gegrond nie, maar in God Wie se woord effektief is (Jes 55:10-11).

- Eties: 'n sin van verantwoordelikheid wat die leser se verpligtinge teenoor die ander ${ }^{20}$ erken en nakom.

Die getuienis, in woord en daad, van individuele gelowiges en die kerk as geloofsgemeenskap is waarskynlik die belangrikste vorm van Teologiese interpretasie (Vanhoozer 2008a:21).

\section{Samevattende opmerkings}

Die publikasie van verskeie reekse teologiese kommentare sedert die jaar 2000 merk die toetrede van Teologiese interpretasie binne die hermeneutiese kader. 'n Gebrek aan goedontwikkelde metodologiese oorwegings, kortwiek egter Teologiese interpretasie van die Bybel. Daar is gepoog om met hierdie artikel 'n bydrae hiertoe te lewer. Drie metahermeneutiese aspekte wat die breë metodologiese onderbou van Teologiese interpretasie uitmaak, naamlik metafisika, epistemologie en etiek is ondersoek.

Die metafisiese oorwegings is ondersoek in terme van die karakter van God as aktiewe teenwoordige kommunikatiewe agent wat die fundamentele hermeneutiese horison uitmaak waarbinne Teologiese interpretasie van die Bybel gepraktiseer word. Kontemporêre bybelse hermeneutiek word tradisioneel bedryf in terme van die 'teks-leser'-teenstelling met menslike agentskap as fokus-kenmerk van albei: fokus op die teks sentreer menslike agentskap op die skep en samestelling van tekste, terwyl fokus op die leser menslike agentskap op die verskeidenheid van leesaktiwiteite sentreer (Bowald 2010:167). Dit stem ooreen met die hoofkategorieë van verstaan wat die hermeneutiese fokus in die onderskeie postAufklarung periodes uitgemaak het: geskiedenis in die modernisme en taal in die postmodernisme (Lombaard 2015:4). Verskeie teologiese interpreteerders verskuif egter die fokus na Goddelike agentskap. Dit is hulle gedagtes wat, na my mening, die grootste bydrae tot nadenke rondom die metodologiese onderbou van Teologiese interpretasie kan maak. Met behulp van die teorie van ontluiking kan die kanon as die resultaat van Goddelike agentskap in terme van 'n hoër orde fenomeen met nuwe ontluikende kategorieë beskryf word. So word die karakter van God as aktiewe teenwoordige kommunikatiewe agent die fundamentele hermeneutiese horison waarbinne Teologiese interpretasie van die Bybel gepraktiseer word.

Die epistemologiese oorwegings is in terme van 'n teofondamentalistiese epistemologie asook hermeneutiese rasionaliteit, genre en die aard van literêre kennis ondersoek. Teofondamentalistiese epistemologie vermy die tradisionele hermeneutiese slaggate - fideïsme aan die een kant en skeptisisme aan die ander kant, terwyl dit epistemiese nederigheid behou (Diller 2007:271). Hermeneutiese 20. Hierdie ander behels God sowel as naaste. 
rasionaliteit is die strewe na literêre kennis. Die epistemologiese veronderstelling dat absolute literêre kennis nie moontlik is nie, maar dat voldoende literêre kennis wel 'n hermeneutiese moontlikheid is (Vanhoozer [1998] 2009:300), is gegrond in die reformatoriese beginsel van die deursigtigheid van die Skrif wat nóg 'n absolute waarde, nóg 'n abstrakte eienskap van die Bybelteks is. Dit is 'n spesifieke funksie, relatief tot die bepaalde doel van die Skrif, naamlik getuienis aangaande Christus. Dit gaan nie soseer oor die voor-die-hand-liggendheid van die Bybel as oor die doeltreffendheid daarvan nie. Die Bybel is duidelik genoeg om die kommunikatiewe handeling doeltreffend te lewer. Dit beteken nie dat die leser alles sal weet wat daar is om te weet met betrekking tot die teks nie, maar dat sy of hy genoeg sal weet om 'n verantwoordelike respons te kan maak ten opsigte van die onderwerp waaroor die teks handel (Vanhoozer [1998] 2009:317).

In kritiese realisme is daar ' $n$ verband tussen die verstaan van realiteit en die verstaan van tekste ten opsigte van die deskriptiewe verwysingsraamwerk (of paradigma, of spesifieke hermeneutiese skema) waarmee ons die realiteit of die teks benader. Dit is nie dat paradigmas of deskriptiewe verwysingsraamwerke die realiteit konstrueer nie, maar dat sekere aspekte van die realiteit slegs na vore tree of aan die lig kom, onder sekere deskriptiewe verwysingsraamwerke (Vanhoozer [1998] 2009:232). Terwyl ons die realiteit of die teks noodwendig benader vanuit 'n deskriptiewe verwysingsraamwerk (of paradigma of spesifieke hermeneutiese skema) wat ons kennis beperk en voorlopig maak, kan die verstaan van die realiteit of die betekenis van die teks waartoe ons toegang kry deur middel van ons verwysingsraamwerk, asook deur middel van genre as 'n bybelse deskriptiewe verwysingsraamwerk steeds ware kennis wees (vgl. Vanhoozer [1998] 2009:323). Die konsep genre as 'n manier van beteken, help die hermeneut om die verskeidenheid van kognitiewe kontak met realiteit wat in die onderskeie Bybeltekste en genres gemaak word, te onderskei. Wat ons in die Skrif het, is realiteit 'onder beskrywing', maar nogtans realiteit (Vanhoozer [1998] 2009:342). Vir Ricoeur (1977:15) bemiddel die verskeie vorms van bybelse diskoers of genres-openbaring op ' $n$ onverminderbare manier - sodanig dat, indien die vorm van die teks versaak word, die inhoud ook verlore gaan omdat genre meer is as 'n klassifiseringsinstrument van literêre vorms - dit is kognitiewe instrumente vir die generering van wêreldbeskouings. Daarom is die soort literêre kennis wat ' $n$ teks bied, afhanklik van die soort literatuur of die genre van die teks. Genre is 'n vorm van sosiale gedrag wat deur reëls gereguleer word en dus kommunikatiewe bevoegdheid vereis (Vanhoozer [1998] 2009:337-338).

Die etiese oorwegings onderliggend aan Teologiese interpretasie is ondersoek. Die moraliteit van literêre kennis vereis balans - balans in terme van nederigheid en ywer, twee hermeneutiese verantwoordelikhede wat mekaar balanseer, asook in terme van skeptisisme en oortuiging. Nederigheid is wat die leser op die teks laat wag eerder as om dit te wil bemeester. Die drie bydraes van nederigheid as hermeneutiese deugde, naamlik metafisiese, epistemologiese en etiese oorwegings is, in terme van die meta-hermeneutiese oorwegings onderliggend aan Teologiese interpretasie, uitgespel.

\section{Erkenning Mededingende belange}

Die outeur verklaar dat sy geen finansiële of persoonlike verbintenis het met enige party wat haar nadelig kon beïnvloed het in die skryf van hierdie artikel nie.

\section{Literatuurverwysings}

Adam A.K.M., Fowl, S.E., Vanhoozer, K.J. \& Watson, F., 2006, 'Preface', in A.K.M. Adam et al. (eds.), Reading Scripture with the church: Toward a hermeneutic for Theological interpretation, pp. 7-13, Kindle edn., Baker Publishing Group, Grand Rapids. https://doi.org/10.1017/cbo9780511621260.001; https://doi.org/10.1017/ cbo9780511617195.002; https://doi.org/10.1017/cbo9780511607585.001

Bartholomew, C., Bartholomew, C.G. \& Beldman, D.J., 2012, Hearing the Old Testament: Listening for God's address, Wm. B. Eerdmans Publishing, Grand Rapids.

Bowald, M.A., 2007, 'Rendering mute the word: Overcoming deistic tendencies in modern hermeneutics: Kevin Vanhoozer as a test case', Westminster Theological Journal 69(2), 367-381.

Bowald, M.A., 2010, 'The character of Theological interpretation of Scripture', International Journal of Systematic Theology 12(2), 162-183. https://doi. org/10.1111/j.1468-2400.2009.00448.x

Briggs, R.S., [2010] 2012, The virtuous reader: Old Testament narrative and interpretive virtue, e-book edn., Baker Academic, Grand Rapids.

Carson, D.A., 2011, 'Theological interpretation of Scripture: Yes, but', in R.M. Allen (ed.), Theological commentary: Evangelical perspectives, pp. 187-207, T\&T Clark International, London.

Diller, K., 2007, 'Does contemporary theology require a postfoundationalist way of knowing?', Scottish Journal of Theology 60(3), 271-293, viewed 27 September 2016, from http:/www.cambridge.org/core

Goldingay, J., 2012, 'Hearing the Old Testament: Listening for God's address', The Journal of Theological Studies 63(2), 663-665. https://doi.org/10.1093/jts/fls142

Green, J.B., 2011, Practicing Theological interpretation: Engaging biblical texts for faith and formation, Baker Academic, Grand Rapids.

Green, J.B. \& Meadowcroft, T. (eds.), 2013, Ears that hear: Explorations in theological interpretation of the Bible., Sheffield Phoenix Press, Sheffield.

Lombaard, C., 2015, 'Mysticism and/in the Old Testament: Methodological orientation and a textual example', HTS Teologiese Studies/Theological Studies 71(1), Art. \#2813, 5 pages. https://doi.org/10.4102/hts.v71i1.2813

Marion, J.L., 1991, God without being: Hors-texte, transl. T.A. Carlson, University of Chicago Press, Chicago.

Marshall, B.D., 1992, 'Meaning and truth in Narrative interpretation', Modern theology 8(2), 173-179. https://doi.org/10.1111/j.1468-0025.1992.tb00274.x

Meadowcroft, T., 2013, 'Introduction: An intepretive conversation', in J.B. Green \& T. Meadowcroft (eds.), Ears that hear: Explorations in theological interpretation of the Bible, pp. 1-10, Sheffield Phoenix Press, Sheffield.

Moberly, W.L., 2011, 'What is theological commentary? An Old Testament perspective', in R.M. Allen (ed.), Theological commentary: Evangelical perspectives, pp. 172-186, T\&T Clark International, London.

Moyaert, M., 2014, 'Paul Ricoeur on biblical hermeneutics', in R. Beringer et al. (eds.) Provoked to speech: Biblical hermeneutics as conversation, pp. 27-50, Peeters, Leuven.

Reese, J.M., [1979] 1990, 'Can Paul Ricoeur's method contribute to interpreting the book of Wisdom?', in M. Gilbert (ed.), La sagesse de l'Ancien Testament, pp. 384-396, Leuven University Press, Leuven.

Ricoeur, P., 1976, Interpretation theory: Discourse and the surplus of meaning, Texas Christian University Press, Fort Worth.

Ricoeur, P., 1977, 'Toward a hermeneutic of the idea of revelation', Harvard Theological Review 70, 1-37. https://doi.org/10.1017/S0017816000017600

Ricoeur, P., 1978, 'The metaphorical process as cognition, imagination, and feeling', Critical Inquiry 5(1), 143-159. https://doi.org/10.1086/447977

Ricoeur, P., [1977] 1994, The rule of metaphor: Multi-disciplinary studies of the creation of meaning in language, Routledge, London.

Ricoeur, P., 1995a, 'naming God', in M.I. Wallace (ed.), Figuring the sacred: religion, narrative and imagination, transl. D. Pellauer, pp. 217-235, Fortress, Minneapolis.

Ricoeur, P., 1995b, 'The summoned subject in the school of the narratives of the prophetic vocations', in M.I. Wallace (ed.), Figuring the sacred: religion, narrative and imagination, transl. D. Pellauer, pp. 267-275, Fortress, Minneapolis.

Treier, D.J., 2008, Introducing Theological interpretation of Scripture: Recovering a Christian practice, Kindle edn., Baker Publishing Group, Grand Rapids, MI.

Vanhoozer, K.J., 2008a, 'Introduction: What is Theological interpretation of the Bible' in K.J. Vanhoozer (ed.), Theological interpretation of the Old Testament: A bookby-book survey, pp. 15-28, Baker Academic, Grand Rapids, MI. 
Vanhoozer, K.J. (ed.), 2008b, Theological interpretation of the Old Testament: A bookby-book survey, Baker Academic, Grand Rapids, MI.

Vanhoozer, K.J., [1998] 2009, Is there a meaning in this text?: The Bible, the reader, and the morality of literary knowledge (Landmarks in Christian Scholarship) Kindle edn., Zondervan, Grand Rapids, MI.

Vanhoozer, K.J., 2010, Remythologizing theology: Divine action, passion and authorship, Cambridge University Press, New York. https://doi.org/10.1017/ CBO9780511675959

Van Huyssteen, J.W., 1999, The shaping of rationality: Toward interdisciplinarity in theology and science, Eerdmans, Grand Rapids.

Van Huyssteen, J.W., 2006, 'When our bodies do the thinking: theology and science converge', American Journal of Theology \& Philosophy 27(2/3), 127-153.

Viljoen, A. \& Venter, P.M., 2013, 'An exploration of the symbolic world of Proverbs 10:1-15:33 with specific reference to "the fear of the Lord"', HTS Teologiese Studies/Theological Studies 69(1), Art. \#2008, 6 pages. https://doi.org/10.4102/ hts.v69i1.2008
Viljoen, A., 2015, 'The structuring considerations of a Ricoeurian hermeneutic employed in a reading of Proverbs 14:2', HTS Teologiese Studies/Theological Studies 71(3), Art. \#2849, 7 pages. https://doi.org/10.4102/hts.v71i3.2849

Viljoen, A., 2017, 'Die verhouding tussen Ou-Testamentiese wetenskap en Teologiese interpretasie van die Bybel: Handelinge 8:26-40 as gevallestudie', HTS Teologiese Studies/Theological Studies, Ingedien om gepubliseer te word.

Wallace, M.I., 1995, 'Introduction', in M.I. Wallace (ed.), Figuring the sacred: religion, narrative and imagination, transl. D. Pellauer, pp. 1-35, Fortress, Minneapolis. https://doi.org/10.1111/1468-0025.00129

Wallace, M.I. 2000, 'From phenomenology to Scripture? Paul Ricoeur's hermeneutical philosophy of religion', Modern theology 16(3), 301-313.

Wimsatt, W.K. \& Beardsley, M.C., 1954, The verbal icon: Studies in the meaning of poetry, Kentucky University Press, Kentucky.

Wittgenstein, L., 1958. Philosophical investigations, 2nd edn., transl. G.E.M. Anscombe, Blackwell Publishers, Oxford. 